\title{
STREAM MOSSES AS A POSSIBLE TOOL IN GEOCHEMICAL PROSPECTING IN EASTERN NOR'TH GREENLAND
}

\author{
Per Mølgaard \& Eckart Håkansson
}

As an extension of the geochemistry programme in eastern North Greenland (Ghisler \& Stendal, 1980; Steenfelt, 1980), a systematic collection of stream mosses was carried out in 1980. This report presents some preliminary results on metal distribution with a discussion of the employed extraction method.

Mosses do not concentrate soil minerals as they have no uptake from the rhizosphere, hence soil mosses are generally of limited use in prospecting. Well known exceptions are the so called 'copper mosses', mainly species of Mielichoferia and Merceya, which are tolerant to metal-rich substrates (Shacklette, 1967; Hartman, 1969) and through their mere presence indicate metal enrichment of their habitat. On the other hand, mosses in general have a pronounced ion exchange capacity (Puustjärvi, 1955; Knight et al., 1961), owing to which stream mosses absorb and concentrate ions dissolved in the stream water. As perennial, long living plants, they may absorb ions over long periods. The amount they absorb will depend on the available concentration in the stream water and, accordingly, may reflect the degree of metal mineralization in upstream areas.

The element concentration in the moss plants is an inactive process influenced by the varying affinity of the metallic ions to the polyuronic acid in the cell wall (Knight et al., 1961). Retension of water dissolved elements is generally high, and in epiphytic mosses from tree trunks it has been found to be higher for elements like $\mathrm{Cu}, \mathrm{Fe}, \mathrm{Cr}, \mathrm{Ni}$, and $\mathrm{Pb}$ than for $\mathrm{Zn}$ and Mn (Rasmussen et al., 1980).

Very little information on actual use of stream mosses in geochemical mapping has been reported apart from the work by Whitehead \& Brooks (1969) and Brooks (1972) for uranium mineralizations in New Zealand. However, in remote areas such as North Greenland, collection of stream mosses may provide an attractive and easy means of obtaining a regional geochemical knowledge as well as detecting possible mineral concentrations.

\section{Material and method}

A total of 64 moss samples were collected in eastern North Greenland by some of the expedition members during the field season 1980 (fig. 27), and in many cases the moss was collected together with samples of stream sediments. The majority of the moss samples may be referred to three well defined regions, the Proterozoic-Cambrian platform between Peary Land and Hagen Fjord, Kronprins Christian Land and and the North Greenland fold belt (cf. the geological maps of this and previous reports). Four samples from isolated localities fall outside these regions.

Only stream mosses were used. Each sample was washed in the stream to remove most of the adherent sediment before the water was pressed out of the plant clump. The sample was left to air dry in a paper bag before packing for shipment to the laboratory in Denmark. Here the samples were soaked in deionised water to wash out as much sediment as possible. 


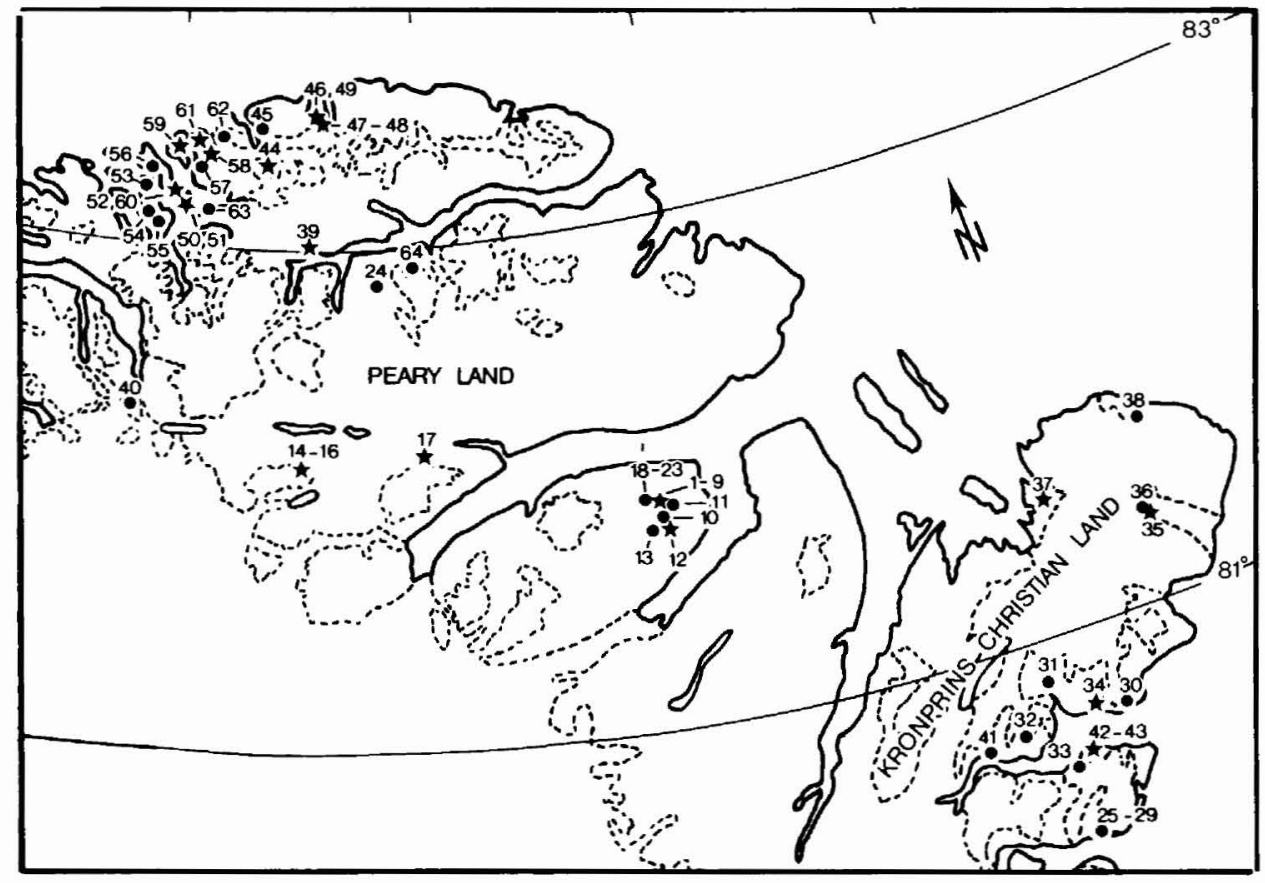

Fig. 27. Sample sites. Asterisks indicate anomalously high concentrations of one or more elements (cf. Table 2).

Twenty-five species of moss have been identified from the samples, but no separation into different species was attempted before the analyses, as the species dependant variation in ion concentration is regarded to be of limited importance (Whitehead \& Brooks, 1969).

After washing, the mosses were dried over-night at $110^{\circ}$ and $2.00 \mathrm{~g}$ were furnace heated at $450^{\circ}$. The ash was dissolved in $5.0 \mathrm{ml} 5 \mathrm{~N} \mathrm{HNO}_{3}$, later diluted to $25 \mathrm{ml} 1 \mathrm{~N} \mathrm{HNO}_{3}$. In this solution the elements were analysed by atomic absorption on a Perkin-Elmer AAS X60.

The seven elements selected for analyses $(\mathrm{Cr}, \mathrm{Cu}, \mathrm{Mn}, \mathrm{Ni}, \mathrm{Pb}, \mathrm{Sr}$ and $\mathrm{Zn}$ ) were previously known to be concentrated by mosses. Furthermore, these elements are all included in the geochemical analyses based on the samples of stream sediments, thus facilitating future comparisons.

Following previously published procedures, the metal concentrations of the samples were calculated on the basis of the total dry matter. However, as discussed below, the figures thus produced (Table 2) possibly include an unknown contribution from the still adherent sediment.

\section{Results}

The mean concentration and the standard deviation $(s)$ of individual elements in all samples were calculated (Table 3). Table 2 shows the concentration found for each element in the samples and indicates values exceeding the mean by $2 s$ and $3 s$ with asterisks. Such samples are further marked with stars in fig. 27 , but it should be stressed that such information should not be generalised and used beyond this present study. 
Table 2. Concentration of elements in the individual samples with information on lithology of the source area

\begin{tabular}{|c|c|c|c|c|c|c|c|c|c|c|}
\hline \multirow[t]{2}{*}{ REGION } & \multirow[t]{2}{*}{ GGU no. } & \multirow{2}{*}{$\begin{array}{c}\text { LOC. } \\
\text { no. }\end{array}$} & \multicolumn{4}{|c|}{ ELEMENT CONCENTRATION, } & \multirow{2}{*}{$\begin{array}{r}\mu g / g \quad D \\
P b\end{array}$} & \multicolumn{2}{|c|}{ ORY MATTER } & \multirow[t]{2}{*}{ LITHOLOGICAL BACKGROUND } \\
\hline & & & $\mathrm{Cr}$ & $\mathrm{Cu}$ & Mn & $\mathrm{Ni}$ & & $\mathrm{Sr}$ & $\mathrm{Zn}$ & \\
\hline \multirow{4}{*}{$\begin{array}{l}\text { KRONPRINS CHRISTIAN } \\
\text { LAND } \\
\text { cf.Map 1, this report }\end{array}$} & $\begin{array}{l}213797 \\
216083 \\
213760 \\
213761\end{array}$ & $\begin{array}{l}37 \\
38 \\
35 \\
36\end{array}$ & $\begin{array}{l}1.2 \\
1.4 \\
1.1 \\
0.4\end{array}$ & $\begin{array}{l}15 \\
18 \\
35 \\
22\end{array}$ & $\begin{array}{r}84 \\
55 \\
221 \\
33\end{array}$ & $\begin{array}{l}22 \\
9 \\
46^{\star \star} \\
1\end{array}$ & $\begin{array}{r}9 \\
7 \\
16 \\
4\end{array}$ & $\begin{array}{r}20 \\
3 \\
9 \\
7\end{array}$ & $\begin{array}{l}55^{\star} \\
23 \\
46 \\
22\end{array}$ & $\begin{array}{l}\text { Thyra o Fm. } \\
\text { Nakkehoved Fm. } \\
\text { Lower Cretaceous } \\
\text { " }\end{array}$ \\
\hline & $\begin{array}{l}213726 \\
213735 \\
213746 \\
213710\end{array}$ & $\begin{array}{l}30 \\
31 \\
34 \\
25\end{array}$ & $\begin{array}{l}3.2 \\
1.8 \\
3.8 \\
1.9\end{array}$ & $\begin{array}{l}22 \\
16 \\
27 \\
26\end{array}$ & $\begin{array}{r}79 \\
154 \\
245 \\
314\end{array}$ & $\begin{array}{r}11 \\
6 \\
10 \\
3\end{array}$ & $\begin{array}{r}9 \\
8 \\
24 \\
16\end{array}$ & $\begin{array}{l}11 \\
17 \\
11 \\
15\end{array}$ & $\begin{array}{l}36 \\
18 \\
59^{\star} \\
35\end{array}$ & 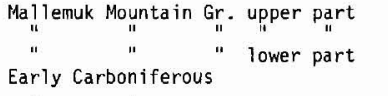 \\
\hline & $\begin{array}{l}213716 \\
213719 \\
213721 \\
213723\end{array}$ & $\begin{array}{l}26 \\
27 \\
28 \\
29\end{array}$ & $\begin{array}{l}1.4 \\
2.7 \\
4.1 \\
1.9\end{array}$ & $\begin{array}{l}30 \\
13 \\
32 \\
24\end{array}$ & $\begin{array}{r}51 \\
306 \\
222 \\
220\end{array}$ & $\begin{array}{r}2 \\
9 \\
5 \\
11\end{array}$ & $\begin{array}{r}9 \\
14 \\
12 \\
9\end{array}$ & $\begin{array}{r}3 \\
7 \\
10 \\
14\end{array}$ & $\begin{array}{r}7 \\
23 \\
19 \\
20\end{array}$ & $\begin{array}{ll}" 1 & " 1 \\
" 1 & " 1 \\
" & 4\end{array}$ \\
\hline & $\begin{array}{l}213736 \\
213743 \\
273907 \\
273918 \\
273919\end{array}$ & $\begin{array}{l}32 \\
33 \\
41 \\
42 \\
43\end{array}$ & $\begin{array}{l}2.7 \\
4.6 \\
1.6 \\
2.9 \\
5.3\end{array}$ & $\begin{array}{r}18 \\
32 \\
18 \\
19 \\
4\end{array}$ & $\begin{array}{r}223 \\
225 \\
99 \\
311 \\
258\end{array}$ & $\begin{array}{r}5 \\
11 \\
2 \\
21 \\
21\end{array}$ & $\begin{array}{c}8 \\
26 \\
4 \\
28 \\
38^{\star}\end{array}$ & $\begin{array}{r}4 \\
7 \\
7 \\
10 \\
10\end{array}$ & $\begin{array}{r}12 \\
41 \\
5 \\
40 \\
30\end{array}$ & $\begin{array}{l}\text { Independence Fjord Group } \\
\text { Precambrian "gneiss complex } \\
\text { " } \\
\text { " }\end{array}$ \\
\hline \multirow{5}{*}{$\begin{array}{l}\text { PROTEROZOIC-CAMBRIAN } \\
\text { PLATFORM } \\
\text { cf.Map 1, Rapport } \\
\text { Grønlands geo1. } \\
\text { Undersøgelse } 88\end{array}$} & $\begin{array}{l}211672 \\
211675 \\
211667 \\
211669\end{array}$ & $\begin{array}{l}20 \\
21 \\
18 \\
19\end{array}$ & $\begin{array}{l}5.2 \\
3.9 \\
5.5 \\
3.6\end{array}$ & $\begin{array}{l}18 \\
15 \\
17 \\
21\end{array}$ & $\begin{array}{l}261 \\
172 \\
126 \\
392\end{array}$ & $\begin{array}{l}5 \\
4 \\
3 \\
3\end{array}$ & $\begin{array}{l}7 \\
1 \\
0 \\
8\end{array}$ & $\begin{array}{l}6 \\
5 \\
6 \\
2\end{array}$ & $\begin{array}{r}13 \\
17 \\
8 \\
11\end{array}$ & $\begin{array}{l}\text { Buen Fm.+ Portfjeld } \underset{" \text { " Fm. }}{\text { " }} \\
\text { Buen Fm. }\end{array}$ \\
\hline & $\begin{array}{l}211634 \\
211677 \\
197108 \\
197110\end{array}$ & $\begin{array}{r}11 \\
22 \\
1 \\
2\end{array}$ & $\begin{array}{l}3.0 \\
3.1 \\
5.5 \\
4.1\end{array}$ & $\begin{array}{l}18 \\
25 \\
21 \\
16\end{array}$ & $\begin{array}{l}191 \\
196 \\
550 \\
527\end{array}$ & $\begin{array}{l}4 \\
3 \\
8 \\
8\end{array}$ & $\begin{array}{l}4 \\
6 \\
8 \\
6\end{array}$ & $\begin{array}{l}3 \\
7 \\
4 \\
5\end{array}$ & $\begin{array}{l}16 \\
19 \\
27 \\
20\end{array}$ & $\begin{array}{l}\text { Fyns So Fm. } \\
\text { Morænesø Fm. (+Portfjeld \& Buen Fm.) } \\
\text { Multicoloured mb.+ Fyns So Fm. }\end{array}$ \\
\hline & $\begin{array}{l}211605 \\
211606 \\
211610 \\
211612\end{array}$ & $\begin{array}{l}3 \\
4 \\
5 \\
6\end{array}$ & $\begin{array}{l}3.5 \\
2.9 \\
1.9 \\
6.0^{*}\end{array}$ & $\begin{array}{l}16 \\
20 \\
41 \\
18\end{array}$ & $\begin{array}{l}123 \\
190 \\
416 \\
183\end{array}$ & $\begin{array}{r}16 \\
6 \\
7 \\
8\end{array}$ & $\begin{array}{l}5 \\
3 \\
6 \\
4\end{array}$ & $\begin{array}{l}4 \\
5 \\
6 \\
6\end{array}$ & $\begin{array}{l}13 \\
17 \\
53^{\star} \\
14\end{array}$ & $\begin{array}{c}\text { Multicoloured mb. } \\
\text { " } \\
" 1 \\
"\end{array}$ \\
\hline & $\begin{array}{l}211615 \\
211618 \\
211621 \\
211628 \\
211682\end{array}$ & $\begin{array}{r}7 \\
8 \\
9 \\
10 \\
23\end{array}$ & $\begin{array}{l}4.6 \\
6.2^{\star} \\
2.7 \\
1.9 \\
2.9\end{array}$ & $\begin{array}{l}28 \\
49 \\
12 \\
30 \\
11\end{array}$ & $\begin{array}{l}362 \\
468 \\
411 \\
144 \\
187\end{array}$ & $\begin{array}{r}11 \\
7 \\
4 \\
2 \\
3\end{array}$ & $\begin{array}{l}5 \\
7 \\
6 \\
4 \\
4\end{array}$ & $\begin{array}{l}6 \\
3 \\
5 \\
9 \\
5\end{array}$ & $\begin{array}{l}24 \\
18 \\
15 \\
24 \\
20\end{array}$ & $\begin{array}{cc}" 1 & " 1 \\
" 1 & " \\
" 1 & " \\
\text { Basal sandstone mb. } \\
\text { (+Morænes } \mathrm{Fm} \text {, to Buen Fm.) }\end{array}$ \\
\hline & $\begin{array}{l}211638 \\
211640 \\
211663 \\
211647 \\
211650 \\
211653\end{array}$ & $\begin{array}{l}12 \\
13 \\
17 \\
14 \\
15 \\
16\end{array}$ & $\begin{array}{l}3.5 \\
2.8 \\
1.7 \\
4.6 \\
8.0^{\star \star} \\
4.9\end{array}$ & $\begin{array}{l}130^{\star \star} \\
23 \\
10 \\
33 \\
20 \\
13\end{array}$ & $\begin{array}{l}228 \\
374 \\
696 \\
277 \\
359 \\
326\end{array}$ & $\begin{array}{r}14 \\
9 \\
11 \\
5 \\
12 \\
7\end{array}$ & $\begin{array}{r}5 \\
4 \\
15 \\
5 \\
7 \\
6\end{array}$ & $\begin{array}{l}7 \\
8 \\
6 \\
5 \\
8 \\
7\end{array}$ & $\begin{array}{r}23 \\
20 \\
12 \\
8 \\
14 \\
11\end{array}$ & $\begin{array}{l}\text { Basal sandstone mb. } \\
\text { " } \\
\text { Inuiteq So Fm. + Portfjeld Fm. } \\
\text { Inuiteq So Fm. } \\
" \text { " }\end{array}$ \\
\hline \multirow{5}{*}{$\begin{array}{l}\text { NORTH GREENLAND } \\
\text { FOLD BELT } \\
\text { cf.Map 2, this report }\end{array}$} & $\begin{array}{l}303619 \\
303633 \\
303657 \\
303644\end{array}$ & $\begin{array}{l}59 \\
60 \\
62 \\
61\end{array}$ & $\begin{array}{l}1.1 \\
0.7 \\
1.3 \\
0.9\end{array}$ & $\begin{array}{l}74^{\star} \\
37 \\
40 \\
42\end{array}$ & $\begin{array}{l}319 \\
166 \\
344 \\
391\end{array}$ & $\begin{array}{r}6 \\
2 \\
3 \\
17\end{array}$ & $\begin{array}{l}9 \\
11 \\
24 \\
41^{\star \star}\end{array}$ & $\begin{array}{l}19 \\
14 \\
17 \\
12\end{array}$ & $\begin{array}{l}36 \\
21 \\
20 \\
44\end{array}$ & $\begin{array}{c}\text { Kap Washington Group } \\
\text { " Wandel Sea sediments }\end{array}$ \\
\hline & $\begin{array}{l}303616 \\
303676 \\
275561 \\
303519\end{array}$ & $\begin{array}{l}58 \\
63 \\
45 \\
50\end{array}$ & $\begin{array}{l}1.6 \\
0.8 \\
0.8 \\
0.9\end{array}$ & $\begin{array}{l}44 \\
17 \\
41 \\
17\end{array}$ & $\begin{array}{r}181 \\
96 \\
166 \\
31\end{array}$ & $\begin{array}{r}9 \\
3 \\
9 \\
28\end{array}$ & $\begin{array}{l}48^{\star \star} \\
14 \\
14 \\
6\end{array}$ & $\begin{array}{r}8 \\
36 \\
10 \\
3\end{array}$ & $\begin{array}{l}32 \\
13 \\
19 \\
12\end{array}$ & $\begin{array}{l}\text { Sydgletscher Group } \\
\text { Polkorridoren Gr.+Frigg Fj.mudst. } \\
\text { Polkorridoren Group }\end{array}$ \\
\hline & $\begin{array}{l}303533 \\
303538 \\
303586 \\
303531\end{array}$ & $\begin{array}{l}52 \\
53 \\
56 \\
51\end{array}$ & $\begin{array}{l}1.4 \\
1.7 \\
1.8 \\
1.5\end{array}$ & $\begin{array}{l}75^{\star} \\
12 \\
48 \\
14\end{array}$ & $\begin{array}{r}117 \\
91 \\
320 \\
149\end{array}$ & $\begin{array}{r}6 \\
5 \\
17 \\
27\end{array}$ & $\begin{array}{r}16 \\
11 \\
25 \\
7\end{array}$ & $\begin{array}{l}12 \\
16 \\
16 \\
47^{\star}\end{array}$ & $\begin{array}{l}13 \\
18 \\
22 \\
26\end{array}$ & $\begin{array}{ll}" \prime \prime & " 1 \\
" ~ & " 1 \\
\text { Polkorridoren + Paradisfjeld Grs }\end{array}$ \\
\hline & $\begin{array}{l}303572 \\
303608 \\
275552 \\
275579\end{array}$ & $\begin{array}{l}55 \\
57 \\
44 \\
46\end{array}$ & $\begin{array}{l}1.6 \\
0.7 \\
0.9 \\
2.0\end{array}$ & $\begin{array}{l}55 \\
26 \\
18 \\
25\end{array}$ & $\begin{array}{l}87 \\
553 \\
746^{\star \star} \\
506\end{array}$ & $\begin{array}{r}4 \\
11 \\
28 \\
17\end{array}$ & $\begin{array}{r}8 \\
9 \\
13 \\
20\end{array}$ & $\begin{array}{l}30 \\
35 \\
54^{\star \star} \\
22\end{array}$ & $\begin{array}{l}19 \\
33 \\
40 \\
29\end{array}$ & 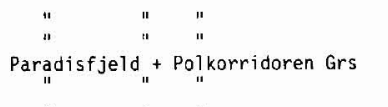 \\
\hline & $\begin{array}{l}275593 \\
275597 \\
275602 \\
303544\end{array}$ & $\begin{array}{l}47 \\
48 \\
49 \\
54\end{array}$ & $\begin{array}{l}0.7 \\
1.5 \\
0.9 \\
0.6\end{array}$ & $\begin{array}{r}27 \\
10 \\
3 \\
8\end{array}$ & $\begin{array}{r}227 \\
388 \\
506 \\
76\end{array}$ & $\begin{array}{l}21 \\
39 * \\
41^{* \star} \\
3\end{array}$ & $\begin{array}{r}14 \\
16 \\
9 \\
3 \\
\end{array}$ & $\begin{array}{l}25 \\
38^{\star} \\
52^{\star \star} \\
27\end{array}$ & $\begin{array}{l}19 \\
35 \\
22 \\
18\end{array}$ & $\underset{\|}{\text { Paradisfjeld "Group }}$ \\
\hline $\begin{array}{l}\text { EARLY PALAEOZOIC } \\
\text { PLATFORM } \\
\text { cf. Map 1, Rapp. } 88 \\
\text { and Map 2, this report }\end{array}$ & $\begin{array}{l}211700 \\
303916 \\
245317 \\
245318\end{array}$ & $\begin{array}{l}24 \\
64 \\
39 \\
40\end{array}$ & $\begin{array}{l}1.1 \\
1.7 \\
2.0 \\
2.8\end{array}$ & $\begin{array}{l}26 \\
17 \\
10 \\
22\end{array}$ & $\begin{array}{l}149 \\
242 \\
325 \\
206\end{array}$ & $\begin{array}{r}4 \\
6 \\
16 \\
11\end{array}$ & $\begin{array}{r}8 \\
11 \\
13 \\
8\end{array}$ & $\begin{array}{r}2 \\
22 \\
11 \\
13\end{array}$ & $\begin{array}{l}16 \\
20 \\
65^{\star \star} \\
18\end{array}$ & $\begin{array}{l}\text { Flysch unit } \\
\text { " } \\
\text { Formation } A+B \\
\text { Buen Fm.+ Bronlund Fjord Group }\end{array}$ \\
\hline
\end{tabular}

Anomalies are indicated by one or two asterisks, based on sample mean plus 2 and 3 times standard deviation, respectively (see Table 2 ). 
Table 3. Analyses of variance and mean element concentrations \pm standard error in samples from the three main regions

\begin{tabular}{|c|c|c|c|c|c|c|c|c|}
\hline \multirow[t]{2}{*}{ REGION } & \multicolumn{2}{|l|}{ No.OF } & \multicolumn{5}{|c|}{ ELEMENT CONCENTRATION, $\mu g / g$ DRY MATTER } & \multirow[b]{2}{*}{$\mathrm{Zn}$} \\
\hline & SAMPLES & $\mathrm{Cr}$ & $\mathrm{Cu}$ & Mn & $\mathrm{Ni}$ & $\mathrm{Pb}$ & Sr & \\
\hline Proterozoic-Cambr. Platform & $n \quad 23$ & $4.0 \pm 0.3$ & $26 \pm 5$ & $311 \pm 32$ & $7.0 \pm 0.8$ & $5.7 \pm 0.6$ & $5.6 \pm 0.4$ & $18 \pm 2$ \\
\hline Kromprins Christian Land & 17 & $2.5 \pm 0.3$ & $22+2$ & $182+24$ & $11.5 \pm 2.7$ & $14.2 \pm 2.3$ & $9.7 \pm 1.1$ & $29 \pm 4$ \\
\hline Fold belt & 20 & $1.2 \pm 0.1$ & $32 \pm 5$ & $273+43$ & $14.8 \pm 2.7$ & $15.9 \pm 2.5$ & $24.6 \pm 3.3$ & $25+2$ \\
\hline F value ${ }^{x}$ & & $28.00^{\star * *}$ & 1.14 & $3.42^{*}$ & $3.70^{*}$ & $8.95^{\star \star \star}$ & $25.70^{\star \star \star}$ & $4.47^{*}$ \\
\hline $\begin{array}{l}\text { 5. Fold Belt + Palaeozoic } \\
\text { Platform }\end{array}$ & 4 & $1.9 \pm 0.3$ & $19 \pm 3$ & $230 \pm 37$ & $9.2 \pm 2.7$ & $10.0 \pm 1.2$ & $12.0 \pm 4.1$ & $30+12$ \\
\hline Mean & 64 & $2.6 \pm 0.2$ & $26 \pm 2$ & $260 \pm 20$ & $10.7 \pm 1.2$ & $11.4+1.1$ & $13.0 \pm 1.5$ & $24+2$ \\
\hline
\end{tabular}

$x$ In the analyses of variance ${ }^{\star \star \star},{ }^{\star \star}$ and $\star$ indicate $\mathrm{P}<0,1 \%, \mathrm{P}<1 \%$ and $\mathrm{P}<5 \%$ respectively,

The general values for $\mathrm{Cu}$ and $\mathrm{Mn}$ found here compare well with the concentration of these elements in similar Alaskan mosses, while the North Greenland material contains only half the amount of $\mathrm{Sr}$ and $\mathrm{Zn}$ compared with the Alaskan mosses (Rastorfer, 1974). It may be noted that the values from North Greenland coincide extremely well with Danish samples of epiphytic mosses (Rasmussen et al., 1980), except for $\mathrm{Pb}$ and $\mathrm{Zn}$ which show much higher levels in the Danish material, presumably as a result of industrial and traffic pollution.

Considering the three main regions, it is evident from Table 3 that the Proterozoic-Cambrian platform has the highest concentration of chromium and manganese and in accordance with this, the only anomalies of chromium are found in this region. Otherwise the platform area has significantly low concentrations of $\mathrm{Ni}, \mathrm{Pb}, \mathrm{Sr}$ and $\mathrm{Zn} . \mathrm{Cu}$ is uniformly distributed in the three regions although one unusually high concentration is found in the platform area (loc. 12, Table 2).

The samples from Kronprins Christian Land have intermediate concentrations of most elements, and only $\mathrm{Mn}$ is significantly lower here than in the other regions. It should be pointed out that the high concentration of $\mathrm{Ni}$ at loc. 35 from Kilen (verified through subsequent analysis) was also found in the lichen Cetraria nivalis collected from approximately the same site as the moss sample (K. Pilegaard, personal communication).

The samples from the North Greenland fold belt have a high metal content particularly with respect to Sr. Accordingly most anomalies for $\mathrm{Cu}, \mathrm{Mn}, \mathrm{Ni}, \mathrm{Pb}$ and $\mathrm{Sr}$ are found in this area. A marked exception to this pattern is the significantly low concentration of Cr.

The results from the Proterozoic-Cambrian platform are analysed in some detail in Table 4 to investigate possible variation according to the lithology of the source area. In this permutation the individual sample may be included in several groups depending on its background in one or more of the four lithological units represented.

Within the region a significantly low Ni concentration was observed in the samples from the Buen Formation. In most cases the Inuiteq Sø Formation has a higher content of metals than the other units, so although the differences are not statistically significant, they probably reflect differences in the lithology of the source area of the samples. 
Table 4. Analyses of variance and mean element concentrations \pm standard error in samples from four lithological units of the Proterozoic-Cambrian platform

\begin{tabular}{|c|c|c|c|c|c|c|c|c|}
\hline \multirow[t]{2}{*}{ LITHOLOGICAL UNIT } & \multicolumn{2}{|l|}{ No.OF } & \multicolumn{3}{|c|}{ ELEMENT CONCENTRATION, } & \multicolumn{2}{|c|}{$\mu g / g$ DRY MATTER } & \multirow[b]{2}{*}{$\mathrm{Zn}$} \\
\hline & SAMPLES & $\mathrm{Cr}$ & $\mathrm{Cu}$ & Mn & $\mathrm{Ni}$ & $\mathrm{Pb}$ & Sr & \\
\hline Buen $\mathrm{Fm}$, & 6 & $4.0 \pm 0.4$ & $25 \pm 3$ & $222 \pm 38$ & $3.5 \pm 0.3$ & $5.3 \pm 1.2$ & $5.2 \pm 0.7$ & $15 \pm 2$ \\
\hline Fyn Sø Fm. + Portfjeld Fm. & 8 & $3.7 \pm 0.4$ & $27 \pm 2$ & $347 \pm 74$ & $5.7 \pm 1.0$ & $7.1 \pm 1.2$ & $5.1 \pm 0.5$ & $18 \pm 2$ \\
\hline Campanuladal Fm. & 13 & $3.7 \pm 0.4$ & $20 \pm 2$ & $320 \pm 42$ & $7.9 \pm 1.1$ & $5.2 \pm 0.4$ & $5.5 \pm 0.4$ & $22 \pm 3$ \\
\hline Inuiteq Sø Fm. & 4 & $4.8 \pm 1.3$ & $23 \pm 4$ & $414+95$ & $8.7 \pm 1.6$ & $8.2 \pm 2.3$ & $6.7 \pm 0.6$ & $11 \pm 1$ \\
\hline F-value ${ }^{x}$ & & 0.59 & 1.87 & 1.22 & $3.26^{*}$ & 1.76 & 1.11 & 2.77 \\
\hline
\end{tabular}

$x$ In the analyses of variance ${ }^{\star \star \star},{ }^{\star *}$ and $\star$ indicate $P<0,1 \%, P<1 \%$ and $P<5 \%$, respectively.

Similar analyses of variance on the samples from the fold belt area also revealed some differences between samples from different lithological units, although statistically less pronounced. However, in a t-test, samples with an exclusive, or partial, Paradisfjeld Group background have been found to contain significantly higher concentrations of $\operatorname{Sr}(\mathrm{P}<0.1$ per cent), $\mathrm{Ni}$ and $\mathrm{Zn}(\mathrm{P}<1$ per cent), and $\mathrm{Mn}(\mathrm{P}<5$ per cent $)$.

\section{Discussion}

As noted above, because of the method employed in this preliminary study, metals which originate from the adherent sediment may be included with those obtained from the moss itself. Such sediment was invariably found to be present in our samples, amounting in some cases to 25-30 per cent of the total dry matter, and we have so far found no way to remove it completely. An adverse effect caused by this sediment is revealed by the fact that powdery chromite (the most likely source of $\mathrm{Cr}$ ions in the area) is soluble, to some extent, in the $5 \mathrm{~N}$ $\mathrm{HNO}_{3}$ acid used to dissolve the ignited sample (H. Stendal, personal communication). Nevertheless, this procedure appears to be considerably more gentle towards minerogenic material than the methods routinely performed in studies of trace elements of such samples (cf. Agemian \& Chau, 1976).

In spite of such shortcomings (which our analyses share with all previous work) it should be made quite clear that the anomalous metal concentrations which appear from the presented results (Table 2) are real, irrespective of the fact that they may not have an exclusive moss origin. Since at least some of the moss-based anomalies are not reproduced in the stream silt analyses from the same sites (A. Steenfelt, personal communication), it is evident that the moss plants contribute significantly to the concentration values found.

In conclusion, therefore, in the North Greenland geochemical environment, which is presumably to a large extent deprived of clay minerals, the ion exchange capacity of stream mosses may be considered of major importance in tracing at least the more mobile metals.

Alternative methods to extract the metal ions from the moss plant efficiently, without interfering with minerogenic matter, are currently being investigated and may, in the future, provide a better background for comparison with other geochemical results from North Greenland. 


\section{References}

Agemian, H. \& Chau, A. S. Y. 1976: Evaluation of extraction techniques for the determination of metals in aquatic sediments. Analyst 101, 761-767.

Brooks, R. R. 1972: Geobotany and Biogeochemistry in Mineral Exploration. New York: Harper \& Row.

Ghisler, M. \& Stendal, H. 1980: Geochemical and ore microscopic investigations on drainage sands from the Peary Land Region, North Greenland. Rapp. Grønlands geol. Unders. 99, 121-128.

Hartman, E. L. 1969: The ecology of the "Copper Moss" Mielichoferia mielichoferi in Colorado. Bryologist 72, 56-59.

Knight, A. H., Crooke, W. M. \& Inkson, H. E. 1961: Cation-exchange capacities of tissues of higher and lower plants and their related uronic acid contents. Nature, Lond. 192, 142-143.

Puustjärvi, V. 1955: On the colloidal nature of peat-forming mosses. Arch. Soc. Vanamo 9 suppl., 257-272.

Rasmussen, L., Pilegaard, K. \& Gydesen, M. 1980: The application of cryptogams as monitoring organisms of metal air pollution in Denmark. Bot. Tidsskr. 75, 93-99.

Rastorfer, J. R. 1974: Element content of three Alaskan-arctic mosses, Ohio J. Sci. 74, 55-59.

Shacklette, H. T. 1967: Copper mosses as indicators of metal concentrations. Bull. U.S. geol. Surv. 1198-G, $17 \mathrm{pp}$.

Steenfelt, A. 1980: The geochemistry of stream silt, North Greenland, Rapp. Grønlands geol. Unders. 99, 129-135.

Whitehead, N. E. \& Brooks, R. R. 1969: Aquatic bryophytes as indicators of uranium mineralization. Bryologist 72, 501-507. 